\title{
Mechanisms involved in the contraceptive effects of ulipristal acetate
}

\author{
María José Munuce ${ }^{1}$, Matías D Gómez-Elías², Adriana M Caille¹, Luis Bahamondes³ , \\ Patricia S Cuasnicú ${ }^{2}$ and Débora J Cohen $^{2}$ \\ ${ }^{1}$ Laboratory of Reproductive Medicine, Biochemical Chemistry Area, School of Biochemical and Pharmaceutical \\ Sciences, National University of Rosario, Rosario, Argentina, ${ }^{2}$ Instituto de Biología y Medicina Experimental (IBYME- \\ CONICET), Buenos Aires, Argentina and ${ }^{3}$ Department of Obstetrics and Gynaecology, School of Medicine, \\ University of Campinas (UNICAMP), Campinas, Brazil
}

Correspondence should be addressed to D / Cohen; Email: dcohen@dna.uba.ar

\begin{abstract}
The use of emergency contraception (EC) methods is increasing worldwide as it constitutes an effective way to prevent unplanned pregnancy after unprotected sexual intercourse. During the last decade, ulipristal acetate (UPA), a selective progesterone receptor modulator, has emerged as the most effective EC pill, and it is now recommended as first-line hormonal treatment for EC in several countries. Its principal mechanism of action involves inhibition or delay of follicular rupture, but only when administered during the follicular phase before the luteinizing hormone (LH) peak. However, considering the high efficacy of UPA, it is possible that it also exerts contraceptive effects besides ovulation. In the present review, we summarize and discuss the existing evidence obtained on the effect of UPA on sperm function and post-ovulatory events as potential additional mechanisms to prevent pregnancy. The bulk of evidence collected so far indicates that UPA would not affect gamete function; however, it could impair embryo-uterine interaction. Thus, besides the described effects on ovarian function, UPA contraceptive effectiveness might also be attributed to post-ovulatory effects, depending on the moment of the female cycle in which the drug is administered.

Reproduction (2020) 159 R139-R149
\end{abstract}

\section{Introduction}

The use of contraceptive methods allows people to fulfill their desired number of children and determine the spacing between pregnancies. The World Health Organization states that ensuring access to preferred contraceptive methods is essential to securing the wellbeing and autonomy of women, while supporting the health and development of communities. Among the different methods available, emergency contraception (EC) involves the use of drugs or devices as a back-up method to prevent pregnancy after unprotected sexual intercourse or after misuse or failure of another contraceptive method.

The copper intrauterine device (Cu-IUD) has been used as EC for more than 35 years and is the most effective method available that can even be left in place as ongoing contraception afterward. Guidelines for the use of Cu-IUDs for EC recommend inserting the IUD within 5 days of unprotected sexual intercourse or no later than 5 days after ovulation if this event can be reasonably determined, to avoid the possibility of an abortifacient effect (Cleland et al. 2012). The mechanisms of action include deleterious effects of the $\mathrm{Cu}^{2+}$ ions on sperm function and fertilization. In addition, $\mathrm{Cu}^{2+}$ ions prevent endometrial receptivity and implantation in case fertilization has already occurred (Cheng et al. 2012). However, its use as EC is limited due to the requirement of trained healthcare professional for the device insertion (Gemzell-Danielsson et al. 2014), and the uncertainty that the Cu-IUD is inserted before the implantation of an embryo has taken place (Cleland et al. 2012).

Considering the fundamental role of progesterone (P4) during the whole fertilization process ranging from ovulation to sperm function, implantation and pregnancy development (Blackmore et al. 1991, Carson et al. 2000, Ramathal et al. 2010, Lishko et al. 2011, Strunker et al. 2011), it is not surprising that several synthetic compounds that present pure antagonist or a mixture of agonist/antagonist actions on $\mathrm{P} 4$ receptors (PR) (Chabbert-Buffet et al. 2005), known as selective PR modulators (SPRM), have been developed with applications in contraception.

Of the existing modulators, mifepristone (RU486) presents anti-P4 activity on PR in humans (Leonhardt \& Edwards 2002). Low doses of mifepristone (10-25 mg) are used as EC in a limited number of countries including Armenia, China, Russia, and Vietnam. However, the fact that higher doses are used for medical termination 
of pregnancy is the reason why it is not worldwide distributed as EC method.

The Yuzpe regimen combining two intakes of the oral contraceptives ethinylestradiol (EE, $100 \mu \mathrm{g}$ ) and levonorgestrel (LNG, $0.5 \mathrm{mg}$ ) has been widely used for EC (Task Force on Postovulatory Methods of Fertility Regulation 1998, Trussell et al. 1998). Today, given the availability of more effective options, this regimen is limited to countries where there is no access to other EC methods. The development of pills containing LNG $(1.5 \mathrm{mg})$ has replaced the Yuzpe regimen. A randomized clinical trial comparing both methods showed that LNG prevents significantly more pregnancies than the Yuzpe regimen, and its effectiveness increases when the drug is administered close to the time of coitus. The mechanism of action of LNG is to delay or inhibit ovulation when given prior to the LH surge (Croxatto et al. 2004), without affecting endometrial development or P4 levels (Durand et al. 2001). In vitro studies did not show any effect of the drug on mouse and human blastocysts development (Munuce et al. 2005, Lalitkumar et al. 2007). Moreover, the effect of LNG on implantation has been largely ruled out (Lalitkumar et al. 2007, Meng et al. 2009, Palomino et al. 2010).

WHO-pioneered trials led to the development of ulipristal acetate (UPA, $17 \alpha$-acetoxy- $11 \beta-(4-\mathrm{N}, \mathrm{N}-\mathrm{di}$ methylamin ophenyl-19-norpregna-4,9-diene-3,20 -dione)), a second-generation SPRM derivative of 19-norprogesterone previously known as CDB-2914. In addition, the National Institute of Child Health and Human Development (NICHD) supported both preclinical and Phase I-II studies. In the last 10 years, UPA has been introduced as an EC pill (30 mg) in more than 50 countries, and it is currently recommended as a first-line hormonal treatment for EC due to its higher effectiveness and similar rate of side effects compared to LNG (Gemzell-Danielsson et al. 2014). In several countries, however, the use of UPA as EC has not been approved yet, although lower doses ( $5 \mathrm{mg}$ ) are authorized for the treatment of uterine fibroids (Levens et al. 2008). A temporal comparison between the aforementioned EC methods is shown in Table 1.

P4 exerts its action on the normal reproductive functions of women through its interaction with two isoforms of intracellular receptors with transcriptional activity, PR-A and PR-B (Mote et al. 1999, Patel et al. 2015). UPA binds with high affinity to both isoforms of $\mathrm{PR}$, exhibiting agonist and antagonist properties (Blithe et al. 2003, Chabbert-Buffet et al. 2005, GemzellDanielsson \& Meng 2010). On the other hand, UPA has a lower binding affinity to the glucocorticoid or androgen receptor than mifepristone (Gemzell-Danielsson \& Meng 2010). UPA is rapidly absorbed after ingestion of a $30 \mathrm{mg}$ pill, reaching maximum concentrations of $176 \pm 89 \mathrm{ng} / \mathrm{mL}$ in the first $2 \mathrm{~h}$, with a half-life of $32.4 \pm 6.3 \mathrm{~h}$ (Snow et al. 2011). This drug is distributed bound to plasma proteins, such as albumin, whereas neither sex hormone-binding globulin (SHBG) nor corticosteroid-binding globulin (CBG) appears to serve as serum carriers for UPA in monkeys or humans (Larner et al. 2000). Its metabolization would be mainly through cytochrome P450 and its mono-demethylated metabolite is pharmacologically active (Snow et al. 2011).

During the past years, efforts have been made to elucidate the mechanisms underlying UPA activity as EC with the idea that a better understanding of its mode of action is crucial to give women the possibility to choose in an informed manner among the different available methods. The present review summarizes the available data on the mechanisms through which UPA may act when used for preventing pregnancy after unprotected sexual intercourse.

\section{Effectiveness of UPA}

The effectiveness of UPA as EC has been evaluated through various clinical trials. A Phase III trial including 2221 women showed that UPA was more effective

Table 1 Temporal evolution of hormonal methods and devices used in EC.

\begin{tabular}{|c|c|c|c|}
\hline Method & Chemical structure & Date of introduction & Worldwide acceptance \\
\hline Cu-IUD & Chemical device & $1970 \mathrm{~s}$ & $\begin{array}{l}\text { Very effective method to prevent pregnancy. It requires technical and } \\
\text { medical expertise and facilities. Uncomfortable insertion of the device. }\end{array}$ \\
\hline Yuzpe & $\begin{array}{l}\text { Steroidal EE }+ \text { Norgestrel } \\
\text { (later replaced by LNG) }\end{array}$ & $1970 \mathrm{~s}$ & $\begin{array}{l}\text { Effective and well tolerated method available without prescription in } \\
\text { many countries. Discontinued due to the risk of venous } \\
\text { thromboembolism and unpleasant side effects of EE. }\end{array}$ \\
\hline Mifepristone & Steroidal, SPRM, P4-antagonist & $1980 \mathrm{~s}$ & $\begin{array}{l}\text { Limited use due to moral and religious reasons as the drug induces } \\
\text { pregnancy termination. }\end{array}$ \\
\hline LNG & Steroidal & $1980 \mathrm{~s}$ & $\begin{array}{l}\text { Twice as effective as the Yuzpe, it is the "gold standard" of oral EC } \\
\text { available without prescription over the world. Effective up to } 72 \mathrm{~h} \\
\text { post-unprotected sexual intercourse. }\end{array}$ \\
\hline UPA & $\begin{array}{l}\text { Steroidal, SPRM, P4 } \\
\text { agonist/antagonist }\end{array}$ & 2009 & $\begin{array}{l}\text { Available under prescription in several countries. Effective up to } 120 \mathrm{~h} \\
\text { post-unprotected sexual intercourse. In several countries, its use is } \\
\text { limited for uterine fibroids treatment. }\end{array}$ \\
\hline
\end{tabular}

For additional information see Goldstuck (2014) and ESHRE CapriWorkshop Group et al. (2015).

EC, emergency contraception; EE, ethinyl estradiol; IUD, Intrauterine device; LNG, levonorgestrel; P4, progesterone; SPRM, selective progesterone receptor modulator; UPA, ulipristal acetate. 
than LNG, even up to $120 \mathrm{~h}$ after unprotected sexual intercourse (Glasier et al. 2010), regardless of the day of the menstrual cycle the participant took the pill. Another study that specifically evaluated its effectiveness between 48 and $120 \mathrm{~h}$ after intercourse showed that the pregnancy rate after UPA intake was only $2.1 \%$, whereas the expected pregnancy rate without protection was $5.5 \%$ (Fine et al. 2010). Moreover, when the pill intake took place between 96 and $120 \mathrm{~h}$, only $1.3 \%$ of women became pregnant (Fine et al. 2010), confirming that the window in which UPA was effective could be extended up to 5 days compared to the 3 days recommended for LNG.

\section{Effects of UPA on ovulation}

A large body of evidence has shown that UPA has an inhibitory effect on ovulation when administered during the follicular phase. In particular, during the mid-follicular phase, with follicles between 14 and 16 $\mathrm{mm}$ in diameter, a single dose between 10 and $100 \mathrm{mg}$ produced a delay in follicular rupture and suppression of plasma levels of estradiol (Stratton et al. 2000). On the other hand, when women with follicles larger than 18 $\mathrm{mm}$ in diameter took the pill, a delay in follicular rupture occurred between 5 and 6 days in 59\% of the cases (Brache et al. 2010). The blockage or delay in ovulation was observed in $100 \%$ of women who at the moment of the pill intake presented low levels of $\mathrm{LH}$, and in $79 \%$ of those who had increased levels of this hormone (Brache et al. 2013). In these cases, the intake of UPA suppressed the increase in $\mathrm{LH}$ and the appearance of the peak. However, once LH levels had reached maximum values at the time of UPA administration, women ovulated normally. Moreover, a pharmacodynamic study based on repeated use of UPA (every 7 or 5 -day pill-intake during 8 weeks) showed that the drug delays follicular rupture but ovulation eventually occurs with time in most subjects (Jesam et al. 2016).

It should be noted that the murine model has become a tool to investigate the molecular mechanisms by which UPA could block the follicular rupture. In mice, the intraperitoneal administration of UPA together with hCG (mimicking the LH peak) prevents ovulation (Palanisamy et al. 2006, Gomez-Elias et al. 2016), constituting a good pre-clinical model for these studies. In this regard, later studies in this animal model demonstrated that the observed anti-ovulatory effect was the consequence of a repression of PR-regulated genes critical for ovulation (Nallasamy et al. 2013). When the drug was administered $8 \mathrm{~h}$ after hCG or later, UPA effectiveness to inhibit ovulation significantly declined (Nallasamy et al. 2013, Gomez-Elias et al. 2016), indicating that female mice respond to UPA in a similar way than humans, and supporting the use of this animal model to further evaluate the mechanisms of action of UPA as EC.
As previously shown, unlike LNG whose anti-ovulatory effects are restricted to the follicular phase prior to the increase in LH levels, UPA inhibits follicular rupture even if it is administered during the $\mathrm{LH}$ surge (Brache et al. 2013). This difference has been the justification for the greater effectiveness of UPA compared to LNG. However, given that the LH peak may occur within the 120-h window women have to take the UPA pill, the anti-ovulatory effect would not seem to be sufficient to justify the high effectiveness described for UPA. In this regard, a Hong Kong-based clinical trial including 700 women who required EC showed that administration of a $30 \mathrm{mg}$ UPA pill is able to prevent pregnancy even after ovulation has occurred (percentage of pregnancies prevented calculated for 650 included patients: postovulation: $51.5 \%$, pre-ovulation: $81.1 \%$ ). Although statistical significance was not reached, the authors attribute it to the modest sample size analyzed in their study (Li et al. 2016). These clinical results emphasize the idea that although today UPA is the most effective oral option as EC, more studies are still required to fully clarify its mechanism of action. In view of this, the higher effectiveness of the drug can be attributed to additional interference on sperm function and/or to post-ovulatory events discussed in the following sections.

\section{Effects of UPA on sperm function}

In their transit through the female reproductive tract, spermatozoa are exposed to increasing levels of P4 secreted by the cumulus cells and the corpus luteum. It has been shown that P4 facilitates the interaction of gametes in the female genital tract in various animal species (Libersky \& Boatman 1995, Holt \& Fazeli 2010) through the regulation of processes associated with sperm capacitation. This hormone induces extracellular $\mathrm{Ca}^{2+}$ influx into the sperm (Blackmore et al. 1991, Lishko et al. 2011, Strunker et al. 2011), protein tyrosine phosphorylation (TyrP) (Chung et al. 2014) and other signaling cascades that end in the occurrence of chemotaxis, hyperactivation and acrosome reaction (Teves et al. 2006, Baldi et al. 2009, Sagare-Patil et al. 2012). Considering that sperm are transcriptionally inactive cells, these effects would be mediated by non-genomic P4 membrane receptors. Although the identity of the protein or protein complex that leads to the occurrence of P4-induced phenomena in sperm has not been elucidated so far, UPA could exert agonist or antagonist action on them, affecting sperm function. In this regard, spermatozoa may be stored up to 5 days within the female genital tract before fertilization, the reason why fertile days of the menstrual cycle are the 5 days preceding ovulation and the day after $\mathrm{LH}$ peak (Wilcox et al. 1995). This period of time would be an opportunity for UPA to interfere with sperm function regardless of the timing of the pill intake and the $\mathrm{LH}$ peak in the pill-user. 
Initial studies in rats evaluated the effect of UPA on the male reproductive tract (Wang et al. 1995). No effect on epididymal maturation, post-meiotic sperm development, spermatogenesis, and fertility were observed. In vitro studies showed that exposure of human sperm to a wide range of UPA concentrations $(1-10,000 \mathrm{ng} / \mathrm{mL})$, including those present in the female serum after EC intake, did not affect sperm survival, signaling events associated with TyrP or spontaneous and human follicular fluid induced-acrosome reaction (Munuce et al. 2012). Nonetheless, UPA prevented DNA damage of human spermatozoa in vitro, probably due to a detoxification activity of the drug of the reactive oxygen species (ROS) produced by sperm metabolism in culture (Munuce et al. 2013). Altogether, these results indicated that sperm capacitation and P4-induced acrosome reaction take place in the presence of UPA with no agonist/antagonist activity of the drug. On the other hand, other authors have described several mild effects of UPA on P4-induced acrosome reaction, hyperactivation and $\left[\mathrm{Ca}^{2+}\right]_{i}$ increase (Ko et al. 2014). In addition, in the presence of a P4 gradient, UPA induced a chemo-repellent behavior in sperm (Guidobaldi et al. 2017). Although this direct effect was observed at lower concentrations than those in pill-users sera, these results opened the possibility that sperm fertilizing ability could be compromised in the presence of UPA.

Competitive assays with fluorescent-labeled P4 showed that a concentration of UPA higher than expected in the plasma of UPA-users $(10,000 \mathrm{ng} / \mathrm{mL}$ vs $100-1000 \mathrm{ng} / \mathrm{mL}$ ) is required to specifically displace labeled P4 from P4-binding sites on human sperm head (Zumoffen et al. 2017), supporting that UPA does not modulate sperm function through the sperm head P4-binding sites. $\mathrm{Ca}^{2+}$ channel CatSper, localized in the sperm flagellum and involved in the rapid $\mathrm{Ca}^{2+}$ influx produced by P4, has been proposed as the sperm P4 receptor (Lishko et al. 2011, Strunker et al. 2011). Despite playing a vital role in the regulation of sperm hyperactivation, it is strongly suspected that P4-induced activation of this channel can also mediate an indirect elevation of $\left[\mathrm{Ca}^{2+}\right]_{i}$ in the head (Singh \& Rajender 2015, Brukman et al. 2019). A possible interaction and/or effect of UPA on this channel requires further investigation.

\section{Effects of UPA on gamete interaction and early embryo development}

As stated before, P4 secreted by the cumulus cells facilitates gamete interaction in several species (Libersky \& Boatman 1995, Holt \& Fazeli 2010). Therefore, gamete interaction was a possible target for UPA actions on events occurring after ovulation and before implantation. Considering the ethical reasons involved in the use of human oocytes for gamete interaction research, an experimental approach through heterologous gametes assays as mouse cumulus penetration and hamster oocyte penetration test (HOPT) allowed the indirect evaluation of UPA effects on human sperm-fertilizing ability. At concentrations comparable to those found in pill-users serum, UPA did not impair the human sperm ability to either penetrate the cumulus or to fuse to and penetrate the egg, supporting the idea that the drug does not interfere with, at least, these stages of the sperm-egg interaction process (Zumoffen et al. 2017).

The use of the mouse model allowed the evaluation of the effect of UPA on the complete homologous in vitro fertilization (IVF) process as well as in early embryo development (Gomez-Elias et al. 2016). When cumulus-egg complexes were used, the presence of the drug did not affect IVF, suggesting that hyperactivation and acrosome reaction, the two critical P4-dependent processes required for fertilization, occurred normally in UPA-incubated mouse spermatozoa.

IVF was also performed with cumulus-free mouse eggs, a condition that not only evidences subtle deficiencies in sperm-fertilizing ability (Nishimura et al. 2004, Da Ros et al. 2008), but in which P4 is not present during sperm capacitation or gamete interaction. In this case, the presence of UPA did not alter the fertilization rate, supporting that the drug does not interfere with sperm-egg interaction (Gomez-Elias et al. 2016).

In vitro and in vivo experiments in mouse showed the lack of effect of UPA on embryo early development, measured not only by the percentage of blastocysts obtained in the presence of the drug but also by the kinetics of in vitro development to the blastocyst stage (Gomez-Elias et al. 2016, Gómez-Elías et al. 2019). These results are similar to those obtained with LNG (Munuce et al. 2005) but differ from those showing that mifepristone impairs mouse embryo development both in vivo and in vitro (Roblero et al. 1987, Yang \& Wu 1990), supporting that the mechanism of action of UPA and LNG might be different from that of mifepristone.

\section{Effects of UPA on oviductal function}

The oviduct plays a fundamental role in the reproductive process being the site where both interaction of gametes as well as development and transport of the resulting embryo take place (Li \& Winuthayanon 2017). Most of these actions are mediated by muscular contractions and ciliary activity in the oviduct (Lyons et al. 2006), regulated by P4 (Mahmood et al. 1998, Wanggren et al. 2008). In accordance with this, the expression of PR in ciliated epithelial cells of adult mice and human oviducts has been demonstrated (Teilmann et al. 2006). Different studies have reported that the pharmacologically relevant dose of UPA inhibits both ciliary beat and muscle contraction of fallopian tube strips in vitro (Li et al. 2014). In this way, the effect of this drug on oviductal physiology could constitute an additional post-ovulatory mechanism of pregnancy 
prevention by interfering with gametes and embryo transport and/or storage.

Sperm can be retrieved from the fallopian tubes within $5 \mathrm{~min}$ to $2 \mathrm{~h}$ after insemination in the vagina (Kunz et al. 1996) and the isthmic region of the tube forms a reservoir that enables sperm to stay vital and maintain their fertilizing capacity for several days up to ovulation (Suarez \& Pacey 2006). Therefore, the effect of UPA on the oviduct could alter sperm interaction with the oviductal epithelium. However, the lack of effect of UPA on the ability of human spermatozoa to interact in vitro with human tubal explants (Zumoffen et al. 2017), supports the idea that sperm binding to the oviduct would not depend on the ciliary beating and/ or contractility. Therefore, impairment of sperm-oviduct interaction and the subsequent sperm distribution would not be a mechanism of UPA-mediated EC.

As stated before, evidence does not support a significant direct effect of UPA on human sperm function nor on sperm-oviductal epithelium interaction. However, these results did not evaluate the possible effect of UPA on in vivo sperm transport through the female genital tract, a parameter that is not feasible or ethical to analyze in humans. It is important to point out that UPA would not alter the cervical mucus viscosity precluding a possible effect on sperm transit to the uterine cavity (Jesam et al. 2016). The development of a mouse model in which UPA was administered just after mating and when ovulation has already occurred showed no effect of the drug on the percentage of fertilized eggs (Gomez-Elias et al. 2016), constituting the first in vivo evidence showing that the administration of UPA does not affect sperm transport or gamete interaction. In addition, the finding that injection of UPA just before mating did not affect in vivo fertilization (Gomez-Elias et al. 2016) indicates that the rapid transport of sperm is also unaffected by UPA.

Transport of the embryo through the oviduct to the site of implantation in the uterus could also be modulated by oviductal mobility and, therefore, it could constitute another possible point of action of UPA. As a consequence, an alteration in embryo transport could result in a desynchronization between the resulting blastocyst and the endometrium for its correct implantation. Although the effect of UPA on human embryo transport has not been studied because of ethical and technical limitations, the results obtained when using animal models have shed light on this possibility. Embryo transport to the uterus was studied in mouse females treated with a single post-ovulatory dose of UPA and no differences were obtained in either the number of collected embryos or the percentage of embryos recovered from the uterus compared to controls (Gómez-Elías et al. 2019), ruling out a potential effect of UPA on this event. This could also be the case in humans considering the fact that the risk of ectopic pregnancies in UPA users did not differ from that observed in the general population (Levy et al. 2014).

In summary, although the in vitro inhibitory effects of UPA on ciliary beating and muscle contraction of the fallopian tubes have been described, studies performed so far indicate that, if any in vivo effects exist, they would not have a strong impact on the transport or interaction of gametes and embryos.

\section{Effects of UPA on uterine physiology and implantation}

P4 plays a fundamental role in implantation by acting on the acquisition of endometrial receptivity, embryo adhesion and decidualization (Ramathal et al. 2010). P4 genomic receptors PR-A and PR-B are expressed in both the epithelium and the uterine stroma (Mote et al. 1999, Patel et al. 2015). In the proliferative phase, both isoforms are present in both compartments, although PR-A is found in greater proportion. After ovulation, the levels of the two isoforms decrease in the glandular epithelium, but persist in the stroma (Mangal et al. 1997, Mote et al. 1999). In particular, the use of mutant mice showed the fundamental role of PR-A in endometrial function: its lack produces a completely altered implantation and decidualization in addition to the inability of the females to ovulate normally (Mulac-Jericevic et al. 2000). In view of this, it is possible that UPA intake after ovulation could modulate the uterine physiology/ receptivity. However, the effect of a single dose of UPA on uterine function has been poorly studied in women. In particular, the ingestion of an unmicronized $50 \mathrm{mg}$ pill of UPA during the mid-follicular phase produced a delay in endometrial maturation (Stratton et al. 2000) while when ingested in the early luteal phase resulted in a dose-dependent decrease in the thickness of the endometrium (Stratton et al. 2010). Although some authors affirm that doses with endometrial effects would not be relevant for EC (Gemzell-Danielsson et al. 2014), others indicate that, in fact, the $30 \mathrm{mg}$ micronized formulation of UPA (currently on the market) would be pharmacokinetically equivalent to the one used by Stratton and collaborators (Mozzanega et al. 2013). On the other hand, the prolonged use of low doses of UPA ( $5 \mathrm{mg} /$ day for 9-13 weeks) for the treatment of uterine leiomyomas has led to numerous studies on the effects of UPA on uterine physiology (Williams et al. 2012, Whitaker et al. 2017). These treatments would produce endometrial histological alterations called PR modulators-associated endometrial changes (PAEC). In particular, the administration of UPA has been associated with low levels of glandular and stromal proliferation. However, it has not yet been clarified if the effects reported on uterine physiology could contribute to the contraceptive action of UPA. In this regard, it has been recently shown that the mid-cycle (when dominant 
follicle diameter reached $20 \mathrm{~mm}$ ) administration of a single dose of UPA modifies the global gene expression of endometrial biopsies taken during the receptive phase, showing changes compatible with a nonreceptive endometrial phenotype (Lira-Albarrán et al. 2017) and changes in genes involved in the process of endometrial decidualization (Lira-Albarrán et al. 2018), a prerequisite for successful implantation.

Although endometrial alterations after UPA intake have been reported, its in vivo impact on implantation has not been evaluated in humans due to ethical reasons. Through an in vitro approach, the effect of the drug on the interaction of human embryos (Berger et al. 2015) or trophoblastic spheroids made from JAr cells (Li et al. 2017) with endometrial constructs or cultures was evaluated. There were no changes in the adhesion of the embryos or spheroids to the endometrial cells with respect to the controls, nor in the levels of genes associated with the implantation process, suggesting that UPA would not affect implantation. However, the endometrial cells used in these studies were not obtained from UPA-treated women. Altogether, these in vitro approaches do not fully-emulate the in vivo implantation process. Once again, the use of animal models allowed further evaluation of the effects of the drug in implantation.

Previous reports in rats and rabbits showed that the administration of a high single dose of UPA at the post- or peri-implantation period is effective in blocking pregnancy (Reel et al. 1998, Hild et al. 2000). However, these experimental designs did not mimic the human situation in which UPA must be taken up to 5 days after sexual relation, meaning during the prereceptive period. More recent experiments in mice, in which the drug was administered during the prereceptive period, better resembling the situation in pilluser women, shed light on the possible in vivo effects of UPA on implantation (Gómez-Elías et al. 2019). In this case, UPA-treated females presented a decrease in the number of conceptuses compared to controls. This decrease was consistent with a lower number of early implantation sites detected in treated females (Fig. 1). It is interesting to note that when UPA was injected closer to the moment of mating, its effect on pregnancy was more variable among treated females (Gómez-Elías et al. 2019). This variability is in agreement with the lower effectiveness of post-ovulatory intake of the drug observed in the clinical trial previously mentioned ( $\mathrm{Li}$ et al. 2016).

The histological and functional analysis of mouse uteri showed that the administration of UPA produced glandular and stromal alterations at the receptive period as well as a completely impaired ability to respond to an artificial decidualization stimulus (Fig. 1). In particular, the histological studies showed a desynchronized combination of glandular and stromal elements in the uteri of the females treated
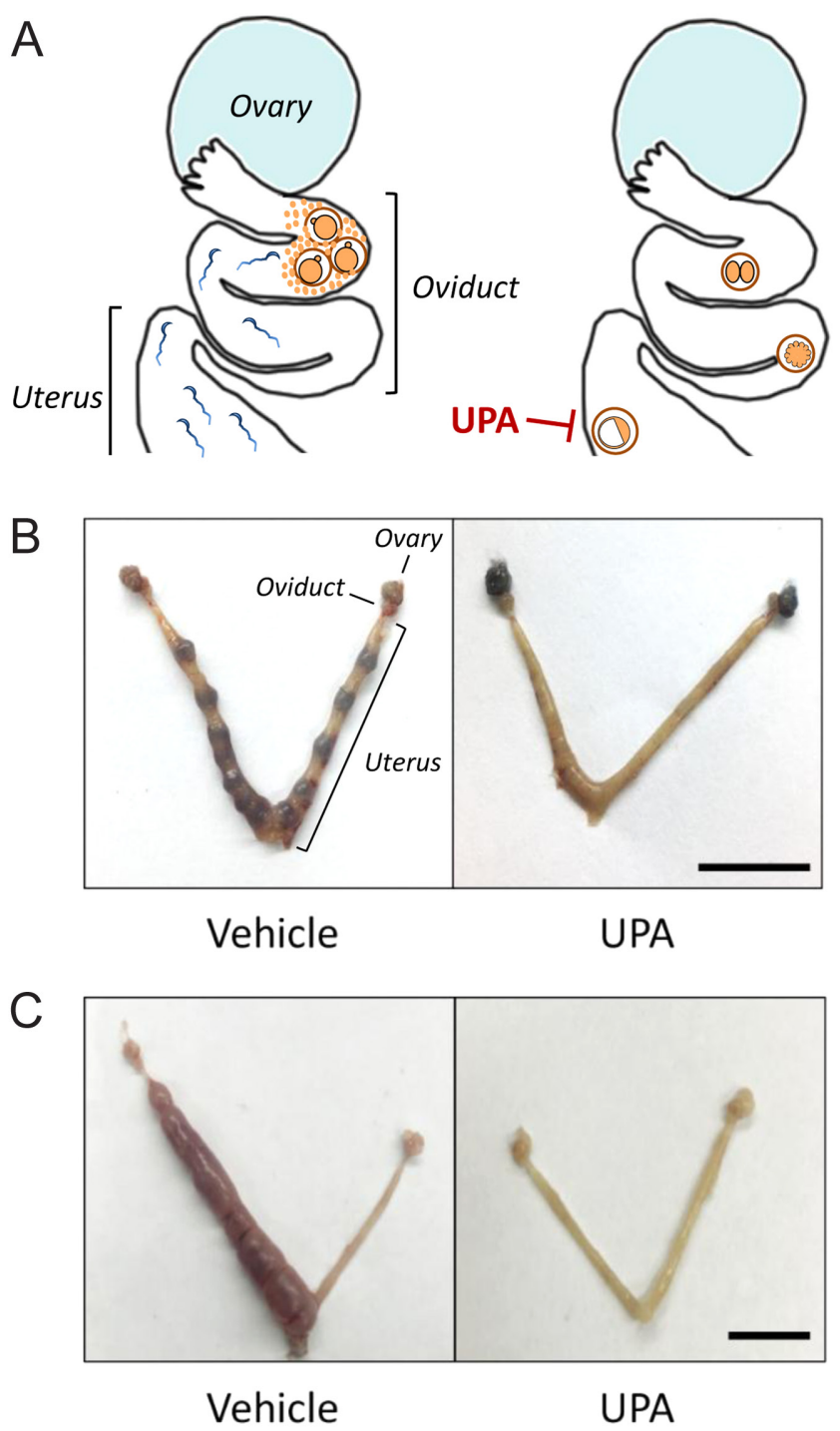

Figure 1 In vivo effects of the post-ovulatory administration of UPA in mouse. (A) Diagram representing the evaluated processes occurring in the female tract after ovulation took place. While no detrimental effects were observed in gamete transport and interaction, and embryo transport and development, UPA interfered with embryouterine interaction. (B) The administration of UPA to females after mating produced a dramatic reduction in the number of early implantation sites (stained with Evans blue dye) compared to controls injected with vehicle. (C) UPA administration abolished the decidualization response when one uterine horn (left horn) received an artificial decidualization stimulus.

with UPA, which could be the cause of the defects in the implantation process. It is important to note that hormonal changes of both endometrial compartments are finely regulated throughout the reproductive cycle (Patel et al. 2015) and, therefore, the dysregulation of this 'cross-talk' between glands and stroma can alter the synchronicity necessary for a correct functionality of the endometrial tissue. This is consistent with studies describing a direct action of UPA on endometrial thickness (Stratton et al. 2010) or on luteal phase length 


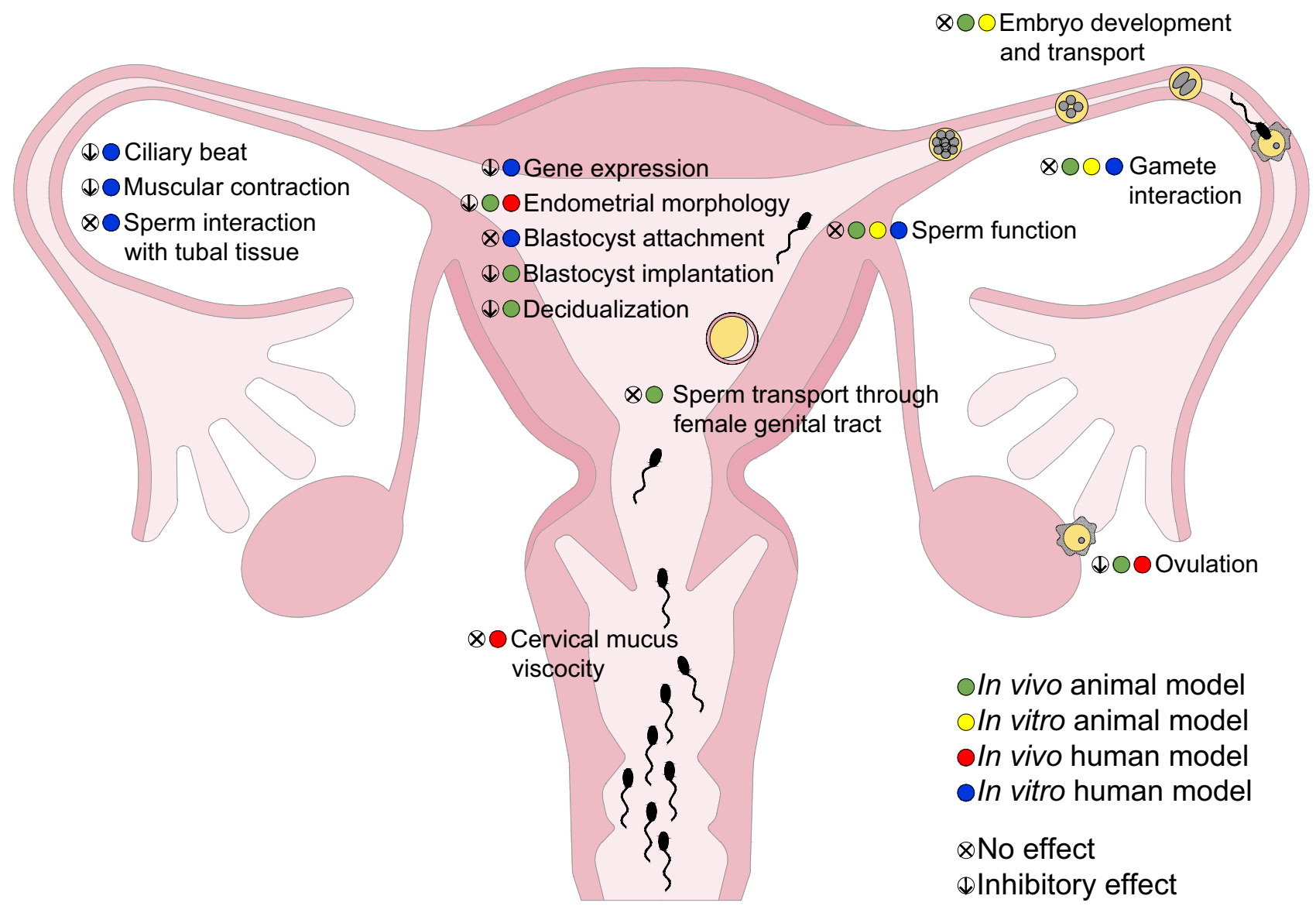

Figure 2 Summary model of UPA effects on the reproductive events from ovulation to implantation. The schematic representation includes the in vivo and in vitro experimental evidence in human and animal models.

(Passaro et al. 2003). Moreover, its prolonged use in low doses for the treatment of uterine leiomyomas resulted in histological alterations with presence of inactive glandular epithelium, altered glandular architecture and aberrant stromal vasculature (Williams et al. 2012, Whitaker et al. 2017). This mouse model, exhibiting a similar phenotype in terms of alterations in uterine morphology, would support the existence of direct effects of UPA on the physiology of the uterus. In addition to the described morphological alterations, uteri of UPA-treated females presented a clear defect to undergo the decidual reaction (Gómez-Elías et al. 2019). It should be noted that the UPA effect observed on the uterine tissue resembles the reproductive phenotype of mice deficient in the PR-A receptor, unable to undergo decidualization (Mulac-Jericevic et al. 2000), indicative of a crucial function of this receptor for normal stromal and endometrial epithelium function. In contrast, the lack of PR-B does not affect the ability of the uterus to maintain pregnancy (MulacJericevic et al. 2003). Furthermore, studies in human breast cancer cells showed that UPA induces an antiproliferative effect in the absence of PR-B, suggesting the importance of the PR-A isoform for the action of this drug (Esber et al. 2015). All this evidence suggests that, in the mouse uterine tissue the action of UPA would be mainly through PR-A.

Altogether, the results in the mouse model provided strong functional evidence favoring the idea that a single post-ovulatory dose of UPA impairs pregnancy probably due to an effect on embryo-uterine interaction.

\section{Final remarks}

The results obtained on the effect of UPA in the different steps of the reproductive process using a variety of in vitro and in vivo models in different species, and including the well-established action on ovulation, are summarized in Fig. 2 and Table 2. The evidence obtained so far revealed that, although UPA would not significantly affect sperm function, interaction of the gametes or the development of the resulting embryos, post-ovulatory administration of UPA could alter the physiology of the uterus, making it less receptive to the implantation process in the murine model. Considering the genomic evidence with endometrial biopsies and 
Table 2 UPA effects on reproductive events in humans and animal models.

\begin{tabular}{|c|c|c|c|}
\hline Reproductive events & Effects & Studies in humans & Studies in animal models \\
\hline Ovulation & $\begin{array}{l}\text { Prevention or delay of follicular rupture } \\
\text { before LH peak }\end{array}$ & $\begin{array}{l}\text { Stratton et al. 2000, Brache et al. } \\
\text { 2010, 2013, Jesam et al. } 2016\end{array}$ & $\begin{array}{l}\text { Palanisamy et al. 2006, } \\
\text { Nallasamy et al. 2013, } \\
\text { Gómez-Elias et al. } 2016\end{array}$ \\
\hline Cervical mucus viscosity & No effect & Jesam et al. 2016 & - \\
\hline \multirow[t]{2}{*}{ Sperm capacitation/function } & No effect & Munuce et al. 2012 & Gómez-Elias et al. 2016 \\
\hline & $\begin{array}{l}\text { Inhibition of P4-induced sperm } \\
\text { parameters/function }\end{array}$ & $\begin{array}{l}\text { Ko et al. 2014, Guidobaldi et al. } \\
2017\end{array}$ & Guidobaldi et al. 2017 \\
\hline Sperm transport & No effect & NDA & Gómez-Elias et al. 2016 \\
\hline Oviductal function & $\begin{array}{l}\text { Inhibition of ciliary beating and muscle } \\
\text { contraction }\end{array}$ & Li et al. 2014 & NDA \\
\hline Sperm-oviduct interaction & No effect & Zumoffen et al. 2017 & NDA \\
\hline Gamete interaction & No effect & Zumoffen et al. 2017 & Gómez-Elias et al. 2016 \\
\hline $\begin{array}{l}\text { Early embryo development and } \\
\text { transport }\end{array}$ & No effect & NDA & Gómez-Elias et al. 2016, 2019 \\
\hline \multirow[t]{2}{*}{$\begin{array}{l}\text { Endometrial morphology and gene } \\
\text { expression }\end{array}$} & Alterations on endometrial physiology & $\begin{array}{l}\text { Stratton et al. 2000, 2010, } \\
\text { Passaro et al. } 2003\end{array}$ & Gómez-Elías et al. 2019 \\
\hline & $\begin{array}{l}\text { Gene expression compatible with } \\
\text { non-receptive endometrium }\end{array}$ & Lira-Albarrán et al. 2017, 2018 & \\
\hline \multirow[t]{2}{*}{ Embryo-uterine interaction } & $\begin{array}{l}\text { No effect in in vitro endometrial } \\
\text { constructs }\end{array}$ & Berger et al. 2015, Li et al. 2017 & \\
\hline & Inhibition of implantation & & Gómez-Elías et al. 2019 \\
\hline
\end{tabular}

NDA, no data available.

the clinical trials mentioned above, this post-ovulatory mechanism could be also operating in humans.

The definition of pregnancy is critical to distinguish between a contraceptive that prevents pregnancy and an abortifacient that terminates it. In biological terms, pregnancy is established when a developing embryo has implanted. However, in several countries, the law establishes that pregnancy begins at fertilization, generating a conflict for the definition of methods that act between fertilization and implantation. The effect observed in mice after a post-ovulatory administration of UPA as well as the gene expression profiles obtained in women support the idea that the drug would act as a contraceptive that inhibits embryo-implantation rather than an abortifacient agent that terminates an implanted embryo. Overall, the results included in this review provide novel information on the mechanism of action of UPA as EC with potential clinical implications and are in accordance with the clinical evidence of its high effectiveness until 5 days after the sexual intercourse occurred.

\section{Declaration of interest}

The authors declare that there is no conflict of interest that could be perceived as prejudicing the impartiality of this review.

\section{Funding}

The project is partially supported by grants BIO 486 (1480/2016) and BIO 565 (5601/2018) from the University of Rosario to M J M and PICT 2016-1057 to D J C from the National Agency of Scientific and Technological Promotion (ANPCyT), Argentina.

\section{Author contribution statement}

M J M, M G E, A M C, L B, P S C and D J C participated in the manuscript writing. $M J M$ conceived and designed Table 1 and Fig. 2, M G E designed Fig. 1 and Table 2, and performed the final edition of the manuscript, A M C collected the bibliography and collaborated with Table 2 design, D J C conceived the manuscript and coordinated all the activities.

\section{References}

Baldi E, Luconi M, Muratori M, Marchiani S, Tamburrino L \& Forti G 2009 Nongenomic activation of spermatozoa by steroid hormones: facts and fictions. Molecular and Cellular Endocrinology 308 39-46. (https://doi. org/10.1016/j.mce.2009.02.006)

Berger C, Boggavarapu NR, Menezes J, Lalitkumar PG \& GemzellDanielsson K 2015 Effects of ulipristal acetate on human embryo attachment and endometrial cell gene expression in an in vitro co-culture system. Human Reproduction 30 800-811. (https://doi.org/10.1093/ humrep/dev030)

Blackmore PF, Neulen J, Lattanzio F \& Beebe SJ 1991 Cell surface-binding sites for progesterone mediate calcium uptake in human sperm. Journal of Biological Chemistry 266 18655-18659

Blithe DL, Nieman LK, Blye RP, Stratton P \& Passaro M 2003 Development of the selective progesterone receptor modulator CDB-2914 for clinical indications. Steroids 68 1013-1017. (https://doi.org/10.1016/s0039128x(03)00118-1)

Brache V, Cochon L, Deniaud M \& Croxatto HB 2013 Ulipristal acetate prevents ovulation more effectively than levonorgestrel: analysis of pooled data from three randomized trials of emergency contraception regimens. Contraception $\mathbf{8 8}$ 611-618. (https://doi.org/10.1016/j. contraception.2013.05.010)

Brache V, Cochon L, Jesam C, Maldonado R, Salvatierra AM, Levy DP, Gainer E \& Croxatto HB 2010 Immediate pre-ovulatory administration of $30 \mathrm{mg}$ ulipristal acetate significantly delays follicular rupture. Human Reproduction 25 2256-2263. (https://doi.org/10.1093/humrep/deq157)

Brukman NG, Nuñez SY, Puga Molina LDC, Buffone MG, Darszon A, Cuasnicu PS \& Da Ros VG 2019 Tyrosine phosphorylation signaling regulates $\mathrm{Ca}^{2+}$ entry by affecting intracellular $\mathrm{pH}$ during human sperm capacitation. Journal of Cellular Physiology 234 5276-5288. (https://doi. org/10.1002/jcp.27337) 
Carson DD, Bagchi I, Dey SK, Enders AC, Fazleabas AT, Lessey BA \& Yoshinaga K 2000 Embryo implantation. Developmental Biology 223 217-237. (https://doi.org/10.1006/dbio.2000.9767)

Chabbert-Buffet N, Meduri G, Bouchard P \& Spitz IM 2005 Selective progesterone receptor modulators and progesterone antagonists: mechanisms of action and clinical applications. Human Reproduction Update 11 293-307. (https://doi.org/10.1093/humupd/dmi002)

Cheng L, Che Y \& Gulmezoglu AM 2012 Interventions for emergency contraception. Cochrane Database of Systematic Reviews 8 CD001324. (https://doi.org/10.1002/14651858.CD001324.pub4)

Chung JJ, Shim SH, Everley RA, Gygi SP, Zhuang X \& Clapham DE 2014 Structurally distinct $\mathrm{Ca}(2+)$ signaling domains of sperm flagella orchestrate tyrosine phosphorylation and motility. Cell 157 808-822. (https://doi.org/10.1016/j.cell.2014.02.056)

Cleland K, Zhu H, Goldstuck N, Cheng L \& Trussell J 2012 The efficacy of intrauterine devices for emergency contraception: a systematic review of 35 years of experience. Human Reproduction 27 1994-2000. (https:// doi.org/10.1093/humrep/des140)

Croxatto HB, Brache V, Pavez M, Cochon L, Forcelledo ML, Alvarez F, Massai R, Faundes A \& Salvatierra AM 2004 Pituitary-ovarian function following the standard levonorgestrel emergency contraceptive dose or a single $0.75-\mathrm{mg}$ dose given on the days preceding ovulation. Contraception 70 442-450. (https://doi.org/10.1016/j.contraception.2004.05.007)

Da Ros VG, Maldera JA, Willis WD, Cohen DJ, Goulding EH, Gelman DM, Rubinstein M, Eddy EM \& Cuasnicu PS 2008 Impaired sperm fertilizing ability in mice lacking cysteine-RIch secretory protein 1 (CRISP1). Developmental Biology 320 12-18. (https://doi.org/10.1016/j. ydbio.2008.03.015)

Durand $M$, del Carmen Cravioto $M$, Raymond EG, Durán-Sánchez O, De la Luz Cruz-Hinojosa M, Castell-Rodríguez A, Schiavon R \& Larrea F 2001 On the mechanisms of action of short-term levonorgestrel administration in emergency contraception. Contraception 64 227-234. (https://doi.org/10.1016/s0010-7824(01)00250-5)

Esber N, Le Billan F, Resche-Rigon M, Loosfelt $H$, Lombès $M$ \& ChabbertBuffet N 2015 Ulipristal acetate inhibits progesterone receptor isoform A-mediated human breast cancer proliferation and BCl2-L1 expression. PLoS ONE 10 e0140795. (https://doi.org/10.1371/journal. pone.0140795)

ESHRE CapriWorkshop Group 2015 Emergency contraception. Widely available and effective but disappointing as a public health intervention: a review. Human Reproduction 30 751-760. (https://doi.org/10.1093/ humrep/dev019)

Fine P, Mathé H, Ginde S, Cullins V, Morfesis J \& Gainer E 2010 Ulipristal acetate taken 48-120 hours after intercourse for emergency contraception. Obstetrics and Gynecology 115 257-263. (https://doi. org/10.1097/AOG.0b013e3181c8e2aa)

Gemzell-Danielsson K, Berger C \& Lalitkumar PG 2014 Mechanisms of action of oral emergency contraception. Gynecological Endocrinology 30 685-687. (https://doi.org/10.3109/09513590.2014.950648)

Gemzell-Danielsson K \& Meng CX 2010 Emergency contraception: potential role of ulipristal acetate. International Journal of Women's Health 2 53-61. (https://doi.org/10.2147/IJWH.S5865)

Glasier AF, Cameron ST, Fine PM, Logan SJ, Casale W, Van Horn J, Sogor L, Blithe DL, Scherrer B, Mathe H et al. 2010 Ulipristal acetate versus levonorgestrel for emergency contraception: a randomised noninferiority trial and meta-analysis. Lancet 375 555-562. (https://doi. org/10.1016/S0140-6736(10)60101-8)

Goldstuck ND 2014 Emergency contraception: history, methods, mechanisms, misconceptions and a philosophical evaluation. Gynecology and Obstetrics 4 224. (https://doi.org/10.4172/21610932.1000224)

Gómez-Elías MD, May M, Munuce MJ, Bahamondes L, Cuasnicú PS \& Cohen DJ 2019 A single post-ovulatory dose of ulipristal acetate impairs post-fertilization events in mice. Molecular Human Reproduction 25 257-264. (https://doi.org/10.1093/molehr/gaz013)

Gomez-Elias MD, Munuce MJ, Bahamondes L, Cuasnicu PS \& Cohen DJ 2016 In vitro and in vivo effects of ulipristal acetate on fertilization and early embryo development in mice. Human Reproduction 31 53-59. (https://doi.org/10.1093/humrep/dev287)

Guidobaldi HA, Cubilla M, Moreno A, Molino MV, Bahamondes L \& Giojalas LC 2017 Sperm chemorepulsion, a supplementary mechanism to regulate fertilization. Human Reproduction 32 1560-1573. (https:// doi.org/10.1093/humrep/dex232)

Hild SA, Reel JR, Hoffman LH \& Blye RP 2000 CDB-2914: anti-proge stational/anti-glucocorticoid profile and post-coital anti-fertility activity in rats and rabbits. Human Reproduction 15 822-829. (https://doi. org/10.1093/humrep/15.4.822)

Holt WV \& Fazeli A 2010 The oviduct as a complex mediator of mammalian sperm function and selection. Molecular Reproduction and Development 77 934-943. (https://doi.org/10.1002/mrd.21234)

Jesam C, Cochon L, Salvatierra AM, Williams A, Kapp N, Levy-Gompel D \& Brache V 2016 A prospective, open-label, multicenter study to assess the pharmacodynamics and safety of repeated use of $30 \mathrm{mg}$ ulipristal acetate. Contraception 93 310-316. (https://doi.org/10.1016/j. contraception.2015.12.015)

Ko JKY, Huang VW, Li RHW, Yeung WSB, Ho PC \& Chiu PCN 2014 An in vitro study of the effect of mifepristone and ulipristal acetate on human sperm functions. Andrology 2 868-874. (https://doi.org/10.1111/j.20472927.2014.00261.x)

Kunz G, Beil D, Deininger H, Wildt L \& Leyendecker G 1996 The dynamics of rapid sperm transport through the female genital tract: evidence from vaginal sonography of uterine peristalsis and hysterosalpingoscintigraphy. Human Reproduction 11 627-632. (https:// doi.org/10.1093/HUMREP/11.3.627)

Lalitkumar PGL, Lalitkumar S, Meng CX, Stavreus-Evers A, Hambiliki F, Bentin-Ley U \& Gemzell-Danielsson K 2007 Mifepristone, but not levonorgestrel, inhibits human blastocyst attachment to an in vitro endometrial three-dimensional cell culture model. Human Reproduction 22 3031-3037. (https://doi.org/10.1093/humrep/dem297)

Larner JM, Reel JR \& Blye RP 2000 Circulating concentrations of the antiprogestins CDB-2914 and mifepristone in the female rhesus monkey following various routes of administration. Human Reproduction $\mathbf{1 5}$ 1100-1106. (https://doi.org/10.1093/humrep/15.5.1100)

Leonhardt SA \& Edwards DP 2002 Mechanism of action of progesterone antagonists. Experimental Biology and Medicine 227 969-980. (https:// doi.org/10.1177/153537020222701104)

Levens ED, Potlog-Nahari C, Armstrong AY, Wesley R, Premkumar A, Blithe DL, Blocker W \& Nieman LK 2008 CDB-2914 for uterine leiomyomata treatment: a randomized controlled trial. Obstetrics and Gynecology 111 1129-1136. (https://doi.org/10.1097/ AOG.0b013e3181705d0e)

Levy DP, Jager M, Kapp N \& Abitbol JL 2014 Ulipristal acetate for emergency contraception: postmarketing experience after use by more than 1 million women. Contraception 89 431-433. (https://doi. org/10.1016/j.contraception.2014.01.003)

Li HW, Liao SB, Yeung WS, Ng EH, O WS \& Ho PC 2014 Ulipristal acetate resembles mifepristone in modulating human fallopian tube function. Human Reproduction 29 2156-2162. (https://doi.org/10.1093/humrep/ deu210)

Li HWR, Li YX, Li TT, Fan H, Ng EHY, Yeung WSB, Ho PC \& Lee KF 2017 Effect of ulipristal acetate and mifepristone at emergency contraception dose on the embryo-endometrial attachment using an in vitro human trophoblastic spheroid and endometrial cell co-culture model. Human Reproduction 32 2414-2422. (https://doi.org/10.1093/humrep/ dex328)

Li HWR, Lo SST, Ng EHY \& Ho PC 2016 Efficacy of ulipristal acetate for emergency contraception and its effect on the subsequent bleeding pattern when administered before or after ovulation. Human Reproduction 31 1200-1207. (https://doi.org/10.1093/humrep/dew055)

Li S \& Winuthayanon W 2017 Oviduct: roles in fertilization and early embryo development. Journal of Endocrinology 232 R1-R26. (https:// doi.org/10.1530/JOE-16-0302)

Libersky EA \& Boatman DE 1995 Effects of progesterone on in vitro sperm capacitation and egg penetration in the golden hamster. Biology of Reproduction 53 483-487. (https://doi.org/10.1095/ biolreprod53.3.483)

Lira-Albarrán S, Durand M, Barrera D, Vega C, Becerra RG, Díaz L, García-Quiroz J, Rangel C \& Larrea F 2018 A single preovulatory administration of ulipristal acetate affects the decidualization process of the human endometrium during the receptive period of the menstrual cycle. Molecular and Cellular Endocrinology 476 70-78. (https://doi. org/10.1016/j.mce.2018.04.010) 
Lira-Albarrán S, Durand M, Larrea-Schiavon MF, González L, Barrera D, Vega C, Gamboa-Domínguez A, Rangel C \& Larrea F 2017 Ulipristal acetate administration at mid-cycle changes gene expression profiling of endometrial biopsies taken during the receptive period of the human menstrual cycle. Molecular and Cellular Endocrinology 447 1-11. (https://doi.org/10.1016/j.mce.2017.02.024)

Lishko PV, Botchkina IL \& Kirichok Y 2011 Progesterone activates the principal Ca2+ channel of human sperm. Nature 471 387-391. (https:// doi.org/10.1038/nature09767)

Lyons RA, Saridogan E \& Djahanbakhch O 2006 The reproductive significance of human Fallopian tube cilia. Human Reproduction Update 12 363-372. (https://doi.org/10.1093/humupd/dml012)

Mahmood T, Saridogan E, Smutna S, Habib AM \& Djahanbakhch O 1998 The effect of ovarian steroids on epithelial ciliary beat frequency in the human fallopian tube. Human Reproduction 13 2991-2994. (https://doi. org/10.1093/humrep/13.11.2991)

Mangal RK, Wiehle RD, Poindexter AN \& Weigel NL 1997 Differential expression of uterine progesterone receptor forms $\mathrm{A}$ and $\mathrm{B}$ during the menstrual cycle. Journal of Steroid Biochemistry and Molecular Biology 63 195-202. (https://doi.org/10.1016/s0960-0760(97)00119-2)

Meng CX, Andersson KL, Bentin-Ley U, Gemzell-Danielsson K \& Lalitkumar PGL 2009 Effect of levonorgestrel and mifepristone on endometrial receptivity markers in a three-dimensional human endometrial cell culture model. Fertility and Sterility 91 256-264. (https://doi.org/10.1016/j.fertnstert.2007.11.007)

Mote PA, Balleine RL, McGowan EM \& Clarke CL 1999 Colocalization of progesterone receptors $\mathrm{A}$ and $\mathrm{B}$ by dual immunofluorescent histochemistry in human endometrium during the menstrual cycle. Journal of Clinical Endocrinology and Metabolism 84 2963-2971. (https://doi.org/10.1210/jcem.84.8.5928)

Mozzanega B, Cosmi E \& Nardelli GB 2013 Ulipristal acetate in emergency contraception: mechanism of action. Trends in Pharmacological Sciences 34 195-196. (https://doi.org/10.1016/j.tips.2013.02.003)

Mulac-Jericevic B, Lydon JP, DeMayo FJ \& Conneely OM 2003 Defective mammary gland morphogenesis in mice lacking the progesterone receptor B isoform. PNAS 100 9744-9749. (https://doi.org/10.1073/ pnas.1732707100)

Mulac-Jericevic B, Mullinax RA, DeMayo FJ, Lydon JP \& Conneely OM 2000 Subgroup of reproductive functions of progesterone mediated by progesterone receptor-B isoform. Science 289 1751-1754. (https://doi. org/10.1126/science.289.5485.1751)

Munuce MJ, Cicaré J, Zumoffen C, Caille A, Ghersevich S, \& Bahamondes L 2013 Effects of ulipristal acetate on sperm DNA fragmentation during in vitro incubation. European Journal of Contraception and Reproductive Health Care 18 355-363. (https://doi.org/10.3109/13625187.2013.813 930)

Munuce MJ, Nascimento JA, Rosano G, Faundes A, Saboya-Brito K \& Bahamondes L 2005 In vitro effect of levonorgestrel on sperm fertilizing capacity and mouse embryo development. Contraception 72 71-76. (https://doi.org/10.1016/j.contraception.2004.12.003)

Munuce MJ, Zumoffen C, Cicare J, Caille A, Ghersevich S, \& Bahamondes L 2012 Effect of exposure to ulipristal acetate on sperm function. European Journal of Contraception and Reproductive Health Care 17 428-437. (https://doi.org/10.3109/13625187.2012.725877)

Nallasamy S, Kim J, Sitruk-Ware R, Bagchi M \& Bagchi I 2013 Ulipristal blocks ovulation by inhibiting progesterone receptor-dependent pathways intrinsic to the ovary. Reproductive Sciences 20 371-381. (https://doi.org/10.1177/1933719112459239)

Nishimura H, Kim E, Nakanishi T \& Baba T 2004 Possible function of the ADAM1a/ADAM2 fertilin complex in the appearance of ADAM3 on the sperm surface. Journal of Biological Chemistry 279 34957-34962. (https://doi.org/10.1074/jbc.M314249200)

Palanisamy GS, Cheon YP, Kim J, Kannan A, Li Q, Sato M, Mantena SR, Sitruk-Ware RL, Bagchi MK \& Bagchi IC 2006 A novel pathway involving progesterone receptor, endothelin-2, and endothelin receptor B controls ovulation in mice. Molecular Endocrinology 20 2784-2795. (https://doi. org/10.1210/me.2006-0093)

Palomino WA, Kohen P \& Devoto L 2010 A single midcycle dose of levonorgestrel similar to emergency contraceptive does not alter the expression of the L-selectin ligand or molecular markers of endometrial receptivity. Fertility and Sterility 94 1589-1594. (https://doi. org/10.1016/j.fertnstert.2009.09.013)

Passaro MD, Piquion J, Mullen N, Sutherland D, Zhai S, Figg WD, Blye R \& Nieman LK 2003 Luteal phase dose-response relationships of the antiprogestin CDB-2914 in normally cycling women. Human Reproduction 18 1820-1827. (https://doi.org/10.1093/humrep/ $\operatorname{deg} 342)$

Patel B, Elguero S, Thakore S, Dahoud W, Bedaiwy M \& Mesiano S 2015 Role of nuclear progesterone receptor isoforms in uterine pathophysiology. Human Reproduction Update 21 155-173. (https:// doi.org/10.1093/humupd/dmu056)

Ramathal CY, Bagchi IC, Taylor RN \& Bagchi MK 2010 Endometrial decidualization: of mice and men. Seminars in Reproductive Medicine 28 17-26. (https://doi.org/10.1055/s-0029-1242989)

Reel JR, Hild-Petito S \& Blye RP 1998 Antiovulatory and postcoital antifertility activity of the antiprogestin CDB-2914 when administered as single, multiple, or continuous doses to rats. Contraception 58 129-136. (https://doi.org/10.1016/s0010-7824(98)00067-5)

Roblero LS, Fernandez O \& Croxatto HB 1987 The effect of RU486 on transport, development and implantation of mouse embryos. Contraception $\quad 36 \quad 549-555 . \quad$ (https://doi.org/10.1016/00107824(87)90007-2)

Sagare-Patil V, Galvankar M, Satiya M, Bhandari B, Gupta SK \& Modi D 2012 Differential concentration and time dependent effects of progesterone on kinase activity, hyperactivation and acrosome reaction in human spermatozoa. International Journal of Andrology 35 633-644. (https://doi.org/10.1111/j.1365-2605.2012.01291.x)

Singh AP \& Rajender S 2015 CatSper channel, sperm function and male fertility. Reproductive Biomedicine Online 30 28-38. (https://doi. org/10.1016/j.rbmo.2014.09.014)

Snow SE, Melillo SN \& Jarvis CI 2011 Ulipristal acetate for emergency contraception. Annals of Pharmacotherapy 45 780-786. (https://doi. org/10.1345/aph.1P704)

Stratton P, Hartog B, Hajizadeh N, Piquion J, Sutherland D, Merino M, Lee YJ \& Nieman LK 2000 A single mid-follicular dose of CDB2914, a new antiprogestin, inhibits folliculogenesis and endometrial differentiation in normally cycling women. Human Reproduction 15 1092-1099. (https://doi.org/10.1093/humrep/15.5.1092)

Stratton P, Levens ED, Hartog B, Piquion J, Wei Q, Merino M \& Nieman LK 2010 Endometrial effects of a single early luteal dose of the selective progesterone receptor modulator CDB-2914. Fertility and Sterility 93 2035-2041. (https://doi.org/10.1016/j.fertnstert.2008.12.057)

Strunker T, Goodwin N, Brenker C, Kashikar ND, Weyand I, Seifert R \& Kaupp UB 2011 The CatSper channel mediates progesterone-induced $\mathrm{Ca} 2+$ influx in human sperm. Nature 471 382-386. (https://doi. org/10.1038/nature09769)

Suarez SS \& Pacey AA 2006 Sperm transport in the female reproductive tract. Human Reproduction Update 12 23-37. (https://doi.org/10.1093/ humupd/dmi047)

Task Force on Postovulatory Methods of Fertility Regulation 1998 Randomised controlled trial of levonorgestrel versus the Yuzpe regimen of combined oral contraceptives for emergency contraception. Lancet 352 428-433. (https://doi.org/10.1016/S0140-6736(98)05145-9)

Teilmann SC, Clement CA, Thorup J, Byskov AG \& Christensen ST 2006 Expression and localization of the progesterone receptor in mouse and human reproductive organs. Journal of Endocrinology 191 525-535. (https://doi.org/10.1677/joe.1.06565)

Teves ME, Barbano F, Guidobaldi HA, Sanchez R, Miska W \& Giojalas LC 2006 Progesterone at the picomolar range is a chemoattractant for mammalian spermatozoa. Fertility and Sterility 86 745-749. (https://doi. org/10.1016/j.fertnstert.2006.02.080)

Trussell J, Rodríguez G \& Ellertson C 1998 New estimates of the effectiveness of the Yuzpe regimen of emergency contraception. Contraception 57 363-369. (https://doi.org/10.1016/s0010-7824(98)00042-0)

Wang C, Sinha-Hikim A \& Leung A 1995 The anti-progestin CDB 2914 has no antifertility effect in male rats. Contraception 51 215-218. (https:// doi.org/10.1016/0010-7824(95)00020-b)

Wanggren K, Stavreus-Evers A, Olsson C, Andersson E \& GemzellDanielsson K 2008 Regulation of muscular contractions in the human Fallopian tube through prostaglandins and progestagens. Human 
Reproduction 23 2359-2368. (https://doi.org/10.1093/humrep/ den260)

Whitaker LHR, Murray AA, Matthews R, Shaw G, Williams ARW, Saunders PTK \& Critchley HOD 2017 Selective progesterone receptor modulator (SPRM) ulipristal acetate (UPA) and its effects on the human endometrium. Human Reproduction 32 531-543. (https://doi. org/10.1093/humrep/dew359)

Wilcox AJ, Weinberg CR \& Baird DD 1995 Timing of sexual intercourse in relation to ovulation. Effects on the probability of conception, survival of the pregnancy, and sex of the baby. New England Journal of Medicine 333 1517-1521. (https://doi.org/10.1056/ NEJM199512073332301)

Williams ARW, Bergeron C, Barlow DH \& Ferenczy A 2012 Endometrial morphology after treatment of uterine fibroids with the selective progesterone receptor modulator, ulipristal acetate. International Journal of Gynecological Pathology 31 556-569. (https://doi.org/10.1097/ PGP.0b013e318251035b)
Yang YQ \& Wu JT 1990 RU 486 interferes with egg transport and retards the in vivo and in vitro development of mouse embryos. Contraception 41 551-556. (https://doi.org/10.1016/0010-7824(90)90063-2)

Zumoffen C, Gómez-Elías MD, Caille AM, Bahamondes L, Cuasnicú PS, Cohen DJ \& Munuce MJ 2017 Study of the effect of ulipristal acetate on human sperm ability to interact with tubal tissue and cumulus-oocytecomplexes. Contraception 95 586-591. (https://doi.org/10.1016/j. contraception.2017.02.019)

Received 1 August 2019

First decision 5 September 2019

Revised manuscript received 25 October 2019

Accepted 4 November 2019 